\title{
EDITORIAL
}

https://doi.org/10.22395/ojum.vl7n35al4

\section{A propósito de los dos años de la firma del acuerdo de paz celebrado entre el Estado colombiano y la guerrilla de las FARC-EP}

El pasado 24 de noviembre se cumplieron dos años de la firma del Acuerdo de Paz entre el Estado colombiano y la guerrilla de las FARC-EP. Durante este tiempo muchas cosas han pasado. El Congreso de la República y el Gobierno Nacional fueron facultados durante seis meses que se prorrogaron por otros seis meses, para implementar el acuerdo mediante normas jurídicas que tuvieron un trámite y control de constitucionalidad especial y abreviado, denominado fast track (Acto Legislativo 01 de 2016 y Sentencia C 699 de 2016).

Se establecieron instituciones indispensables para la materialización del acuerdo tales como la Jurisdicción Especial para la Paz (JEP) y la Comisión para el Esclarecimiento de la Verdad, la Convivencia y la No Repetición (Acto Legislativo 01 de 2017 y Sentencia C 674 de 2017). Se elevó a rango constitucional lo acordado, relacionado con derechos fundamentales y derecho internacional humanitario y se le dio vigencia hasta el 7 de agosto del 2030, con lo que se buscó blindar el acuerdo de las coyunturas políticas que buscaran desconocerlo durante los siguientes tres periodos presidenciales (Acto Legislativo 02 de 2017 y Sentencia C 630 de 2017).

Durante el año que duró la competencia para expedir normas mediante trámite abreviado, el Congreso de la República y el Gobierno Nacional expidieron cuarenta y seis normas entre actos legislativos, leyes y decretos con fuerza de ley y la Corte Constitucional profirió cuarenta sentencias de constitucionalidad, sin embargo, la mayor parte de lo acordado se deberá implementar mediante trámite ordinario, lo que requerirá no solo de más tiempo, sino también de la voluntad política de las nuevas fuerzas que hacen parte del Congreso que se posesionó el 20 de julio del 2018 y el nuevo gobierno posesionado el 7 de agosto del mismo año.

Los partidos políticos críticos del acuerdo han ganado espacios en el Congreso de la República y a ellos se han unido otras fuerzas, incluso algunas que durante el gobierno Santos estuvieron a favor del acuerdo y que también ganaron la presidencia de la República, pues se dieron cuenta que electoralmente era más rentable atacar al acuerdo que defenderlo. 
Desde el plebiscito del 2016, los colombianos seguimos polarizados y mientras tanto, vemos como el Acuerdo de Paz se queda en el papel e incluso en zonas donde las FARC-EP dejaron un vacío de poder, los espacios los llenan otros actores ilegales. El incremento de la violencia en algunas partes del país, el asesinato de líderes sociales, los programas fallidos de reincorporación de excombatientes, el aumento de los cultivos ilícitos, son algunos de los problemas por los que atraviesa lo pactado.

Mientras el mundo mira a Colombia como un laboratorio de paz, un sector importante de la población colombiana no solo rechaza a las FARC-EP -ahora como partido político- y su presencia en el Congreso, sino también la reintegración de los exguerrilleros a la vida social y es este, tal vez, el principal enemigo del acuerdo pues muchos colombianos no están dispuestos a perdonar.

En Colombia, un país de desmovilizaciones frustradas, corremos el riesgo de repetir la historia, he ahí la importancia de analizar temas relacionados con el Acuerdo de Paz que buscó el fin a un conflicto armado de más de cincuenta años. En este sentido, Opinión Jurídica, a dos años de haberse firmado el acuerdo, pone a consideración de la comunidad académica y científica su número especial 2018. Son trece artículos de autores colombianos, también de Brasil y Chile que de manera comprometida quieren hacer su aporte para la comprensión de nuestra realidad.

En el país se llegó a pensar que las FARC-EP eran la causa de muchos de nuestros problemas, pero no es así, ellos son consecuencia de estos y mientras la pobreza, la falta de oportunidades, y la desigualdad, sigan siendo tan grandes en Colombia, seguirá habiendo combustible que alimente la guerra.

David Mendieta 